\title{
Sverre Sandberg valgt til president i EFLM
}

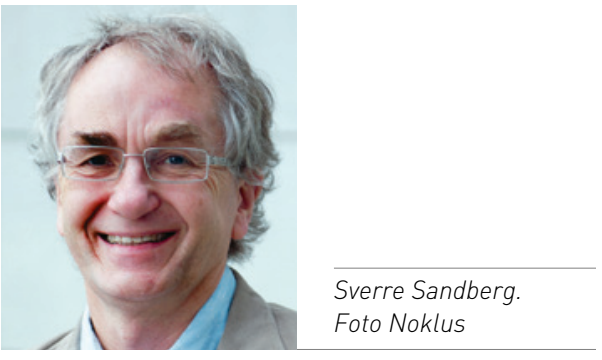

Sverre Sandberg (f. 1950), leder i den ideelle, landsdekkende organisasjonen Norsk kvalitetsforbedring av laboratorievirksomhet utenfor sykehus (Noklus), er valgt til president for European Federation of Clinical Chemistry and Laboratory Medicine (EFLM) for perioden 2016-18.

Sandberg er dessuten leder av Nasjonalt kompetansesenter for porfyrisykdommer (NAPOS), overlege ved Laboratorium for klinisk biokjemi ved Haukeland universitetssykehus, professor ved Universitetet i Bergen og æresmedlem i Norsk Selskap for medisinsk biokjemi (NSMB).
Han tok medisinsk embetseksamen i Bergen i 1975, doktorgraden i 1982 og ble godkjent spesialist i medisinsk biokjemi i 1984 .

European Federation of Clinical Chemistry and Laboratory Medicine ble grunnlagt i 2007 og har som formål å samle nasjonale foreninger for klinisk kjemi og laboratoriemedisin og å skape en plattform for alle europeiske spesialister i laboratoriemedisin.

\section{Gunn Marit Seberg}

Tidsskriftet

\section{Prisbelønte legeforskere}

\section{Kvaliteten på en publikasjon utgått fra det norske legeforskningsinstituttet LEFO høster internasjonal anerkjennelse.}

Legeforskningsinstituttet har gjennom årene arrangert en rekke internasjonale og tverrfaglige forskersamlinger, flere av dem med vitenskapelig publisering som resultat. Dette gjaldt også symposiet som LEFO arrangerte sommeren 2014, hvor forholdet mellom legers profesjonelle tilfredshet, kvalitet på behandlingen og styring og organisering av helsetjenesten var tema (Tidsskr Nor Legeforen 2015; 135: 971). Til dette symposiet - finansiert av Norges forskningsråd, Legeforeningen, Sykehjelps- og pensjonsordningen for leger og Senter for profesjonsstudier ved Høgskolen i Oslo og Akershus - hadde LEFO invitert forskere fra Europa og USA til å holde innlegg om ulike sider ved problemstillingen. Innlegg og kommentarer ble siden omarbeidet til artikler publisert i et spesialnummer av tidsskriftet Professions \& Professionalism (nr. 1/2015) hvor LEFOs seniorforsker Berit Bringedal var gjesteredaktør.

En av artiklene i denne temautgaven ble nylig kåret til beste artikkel om medisinsk profesjonalitet av American Board of Internal Medicine (www.abimfoundation.org). Artikkelen (https://journals. hioa.no/index.php/pp/article/view/954) drøfter betydningen av legers helse og jobbtilfredshet på kvaliteten på det medisinske arbeidet. Forfatterne Casalino \& Crosson presenterer forskning på feltet (se side 851) og konkluderer med at helse og tilfredshet har betydning for kvaliteten, men at det trengs mer data og bedre studier. Se for øvrig fulltekstversjoner og nærmere omtale på www.legeforsk.org.

- Dette er en anerkjennelse vi setter stor pris på. Det viser også betydningen av tverrvitenskapelig samarbeid på tvers av landegrensene og behovet for å oppheve det skarpe skillet vi hittil har hatt

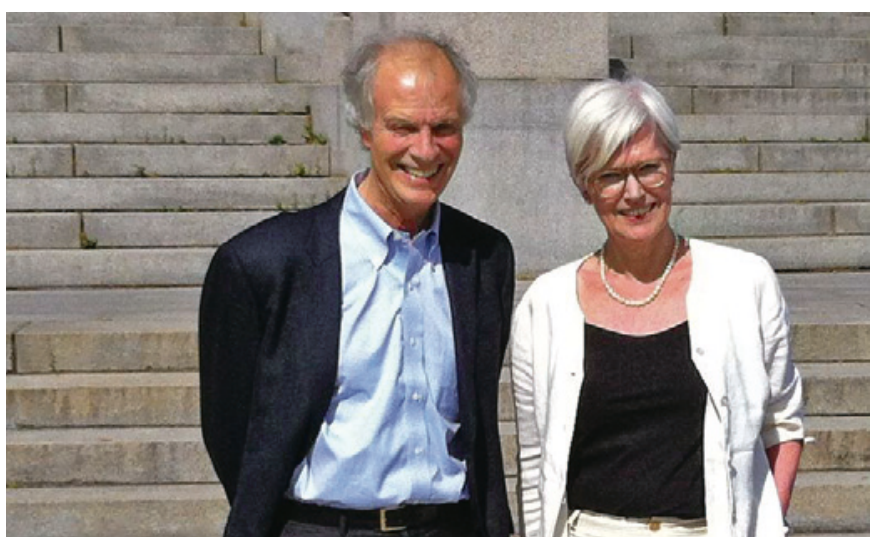

Prisvinnende førsteforfatter, Lawrence P. Casalino, lege og professor ved Weill Cornell Medical College i New York, og gjesteredaktør for artikkelsamlingen i Professions \& Professionalism, Berit Bringedal, sosiolog og seniorforsker ved LEFO - Legeforskningsinstituttet. Foto privat

mellom medisinernes forskning på den ene siden og det samfunnsvitenskapelige blikket på den annen, kommenterer LEFOs instituttsjef Karin Isaksson Rø.

\section{Kari Ronge}

LEFO - Legeforskningsinstituttet 